\title{
PEMETAAN KAWASAN POTENSI RAWAN LONGSOR BERBASIS DATA ANALISIS SISTEM INFORMASI GEOGRAFIS DI KOTA CIMAHI
}

\author{
AC Taruna ${ }^{1 *}$, Lili Soemantri ${ }^{2}$, Iwan Setiawan ${ }^{3}$ \\ ${ }^{123}$ Pendidikan Geografi, FPIPS, Universitas Pendidikan Indonesia, Bandung, Indonesia \\ *Adityacamdra@gmail.com
}

\begin{tabular}{lcc}
\hline \multicolumn{3}{c}{ INFO ARTIKEL } \\
\hline \multicolumn{2}{l}{ Riwayat } & Artikel: \\
Dikirim & $:$ & $23-06-2021$ \\
Disetujui & $:$ & $12-08-2021$ \\
Diterbitkan & $:$ & $13-08-2021$
\end{tabular}

Kata kunci:

Pemetaan, Sistem Informasi

Geografis, Longsor, Overlay

\begin{abstract}
ABSTRAK
Abstract: Cimahi City is a city that is included in the administrative area of West Java with a geographical location of 107³0'30" East Longitude $107^{\circ} 34^{\prime} 30^{\prime \prime}$ and $6^{\circ} 50^{\prime} 00^{\prime \prime}-6^{\circ} 56^{\prime} 00^{\prime \prime}$ South Latitude. Cimahi city has an altitude between 700-1000 meters above sea level. Looking at the topography of the Cimahi city area, the suburbs of Cimahi, especially the northern Cimahi sub-district and the southern Cimahi sub-district, have a slope level that is quite potential to experience natural disasters in the form of landslides. Cimahi needs to be carried out utilizing a geographic information system where various parameters that affect the occurrence of landslides in Cimahi City need to be scored into several classifications from very low, low, medium, high and very high classifications after that the ovelay method is carried out to combine various existing parameters and then proceed with tools in the form of intersect so that the data will be superimposed where this data describes the level of potential landslide disaster in Cimahi City.
\end{abstract}

Abstrak: Kota Cimahi adalah kota yang masuk pada daerah administratif Jawa barat dengan letak geografis 107'30'30', Bujur Timur 107³4'30' dan 650'00' '-6 56'00' Lintang Selatan dimana kota cimahi memiliki ketinggian antara 700-1000 mdpl.Melihat topografi kawasan kota cimahi pinggiran kota cimahi terutama kecamatan Cimahi utara dan kecamatan Cimahi selatan memiliki tingkat kemiringan lereng yang cukup berpotensi mengalami bencana alam berupa longsor.Sehingga dalam hal ini pemetaan kawasan rawan bencana longsor di kota cimahi perlu dilakukan memanfaatkan sistem informasi geografis dimana berbagai parameter yang mempengaruhi terjadinya longsor di Kota cimahi perlu dilakukan pengskoran menjadi beberapa klasifikasi dari klasifikasi sangat rendah,rendah,sedang,tinggi dan sangat tinggi setelah itu dilakukan metode ovelay untuk menggabungkan berbagai parameter yang ada lalu dilanjutkan dengan tools berupa intersect sehingga data akan ditumpangtsusunkan dimana data ini menggambarkan tingkat potensi bencana longsor di Kota cimahi. 


\section{PENDAHULUAN}

Bencana longsor merupakan salah satu bencana yang paling umum terjadi di negara tropis seperti Indonesia dimana curah hujan yang tinggi dan morfologi serta tingkat kelerengan yang curam mengakibatkan bencana longsor ini bencana yang sering terjadi di hampir seluruh kota di Indonesia

Terjadinya bencana longsor ini tentunya mengakibatkan berbagai macam kerugian baik dari segi fisik maupun ekonomi dan mental bagi masyarakat yang terkena longsor secara langsung.Tentunya hal ini tidak dapat dibiarkan terus menerus mengingat adanya ketidakstabilan iklim di Indonesia dan beberapa bulan terakhir ini Indonesia terkena dampak dari la nina dimana suhu permukaan air laut meningkat sehingga memicu tingginya pembentukan awan yang berujung pada tingginya curah hujan yang terjadi di hampir seluruh kawasan di Indonesia.Proses terjadinya La nina dikarenakan adanya arus air laut yang panas yang berasal dari benua amerika selatan bergerak kea rah barat menuju samudra pasifik dimana suhu air yang panas memicu tingginya produksi uap air yang mengakibatkan curah hujan yang tinggi di kawasan Indonesia sejalan dengan penelitian yang dilakukan dengan(Safitri, 2015).

Menurut klasifikasi dan jenisnya longsor dibagi menjadi 6 bagian dimana tiaptiap bagian memiliki karakteristik tersendiri (Apriyono, 2009)

1) Longsoran (Slides) : gerakan tanah ini diakibatkan adanya bidang lemah atau bidang datar dimana terjadi fenomena diskontinuitas pada tanah sehingga terjadi kesejajaran dengan permukaan lereng sehingga terjadi gerakan tanah secara trasnlasi.

2) Robohan (Topless) Longsoran ini pada umumnya terjadi akibat adanya peristiwa jatuhnya batuan batuan dan material lain dengan tingkat kemiringan yang sangat curam.

3) Jatuhan (Falls) Longsoran ini adalah merupakan peristiwa bergeraknya material material pembentuk lereng seperti batuan dimana geraknya mencakup bergerak dengan cepat, menggelinding dan lompatan batuan menuruni permukaan lereng.

4) Aliran (Flow) Merupakan peristiwa longsor dimana material yang mengalami pergerakan adalah material cairan padat dan pada umumnya hanya terjadi pada daerah yang sempit.

5) Sebaran (Spreads) merupakan longsor yang hasil dari kombinasi gerakan tanah dan jatuhan batuan yang bergerak kea rah material lunak yang ada dibawahnya dan pada umumnya longsoran ini menyebar kearah samping karna permukaan lereng yang datar.

6) Komplex (Combination) adalah jenis longsor dimana longsor ini merupakan kombinasi satu jenis longsoran dengan jenis longsoran yang lainya sehingga disebut juga jenis longsoran kombinasi.

Kota Cimahi memiliki ketinggian bervariasi antara 700-1000 mdpl dengan topografi berupa perbukitan ini mengakibatkan kota cimahi memiliki daerah daerah rawan bencana longsor terutama pada kawasan Cimahi bagian Utara dan Cimahi bagian selatan.Pada dasarnya Longsor merupakan peristiwa alamiah dimana tanah mengalami pergeseran dari tempat semula dikarenakan berbagai faktor alamiah yang terjadi pada kondisi tanah.Pada dasarnya peristiwa longsor dapat dikatakan sebuah bencana apabila berdampak pada kehidupan manusia dan mengakibatkan dampak ekonomi maupun fisik.

Kota cimahi saat ini termasuk kawasan padat penduduk dimana lahan dengan luas 4023,73 ha ditempati sekitar 600000 jiwa dimana artinya ada sekitar 1331 jiwa per km persegi ini mengakibatkan adanya perluasan kawasan pemukiman di kawasan kota cimahi dan berakhir pada tingkat konversi lahan yang semula daerah tangkapan air hujan seperti hutan dan areal persawahan saat ini mayoritas berubah menjadi kawasan pemukiman dan kawasan Industri.Hal ini mengakibatkan daerah rawan longsor di kota cimahi menjadi semakin luas karna bukan hanya faktor alamiah seperti curah hujan,kemiringan lereng,jenis batuan dan jenis tanah yang mempengaruhi namun juga diakibatkan adanya faktor manusia yang melakukan pembangunan kawasan pemukiman di tempat yang tidak semestinya sehingga hal mengakibatkan kawasan rawan longsor di kota cimahi semakin luas.Tanah Longsor merupakan sebuah bencana alam yang merupakan kombinasi dari berbagai faktor seperti gejalan alam dan faktor pengelolaan dan 
pemanfaatan lahan oleh manusia(Suwaryo \& Yuwono, 2017).

Sistem Informasi geografis merupakan sebuah sistem yang diciptakan untuk menghimpun dan menganalisis data selain itu sistem informasi geografis dapat menggabungkan beberapa data yang sebelumnya sudah ada menjadi sebuah data baru yang dapat dimanfaatkan untuk kepentingan khalayak banyak.Selain itu SIG adalah alat yang berfungsi untuk mengumpulkan data data yang berkaitan dengan berbagai faktor geografis terutama dalam hal analisis dan rekayasa (Samsul Arifin, Ita Carolina, 2006)

\section{METODE PENELITIAN}

Metode yang digunakan pada penelitian ini adalah metode Overlay menggunakan tools intersect .Metode Overlay adalah metode menggabungkan 1 layer data dengan data lainya sehingga menghasilkan data baru parameternya antara lain adalah curah hujan ,kemiringan lereng,jenis tanah,jenis batuan dan tutupan lahan yang ada selanjutnya akan melalui tahap pengharkatan dimana berbagai indicator terjadinya longsor diurutkan dari yang paling rendah hingga tinggi lalu selanjutnya dilakukan intersect pada aplikasi arcgis untuk menumpangsusunkan setiap 2 atau lebih data attribute dari sebuah polygon untuk menemukan hasil nilai dari setiap data

\section{Waktu dan Lokasi Penelitian}

Penelitian dilaksanakan pada bulan mei 2021 dengan lokasi penelitian adalah kota Cimahi dengan letak geografis $107^{\circ} 30^{\prime} 30^{\prime \prime}$ Bujur

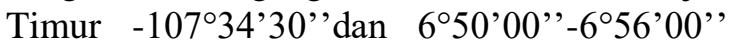
Lintang Selatan

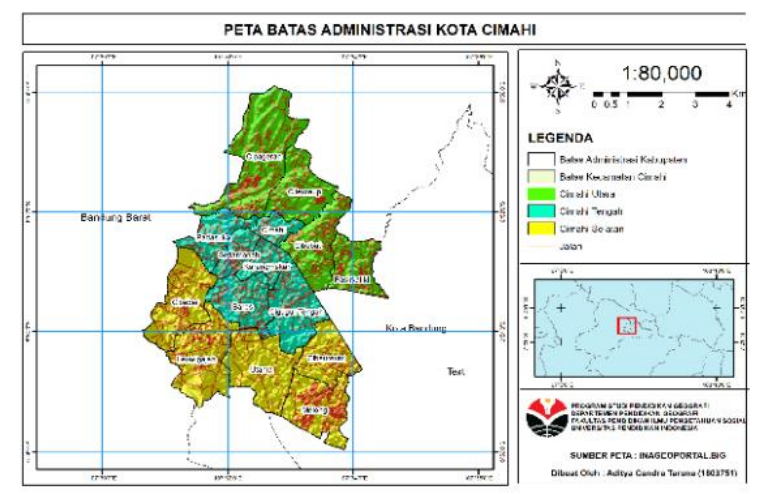

\section{Alat dan Bahan}

- Laptop dengan spesifikasi yang cukup

- Software Arcmap 1.0.3

- Microsoft office word 2016

- Microsoft excel 2016

Metode pengumpulan, pengolahan, dan Analisis Data

Penelitian ini dalam tahap mengumpulkan sumber data parameter terjadinya longsor memanfaatkan data sekunder mencakup peta topografi,Curah hujan dan jenis tanah yang ada di Kota Cimahi

\section{Diagram Alir Penelitian}

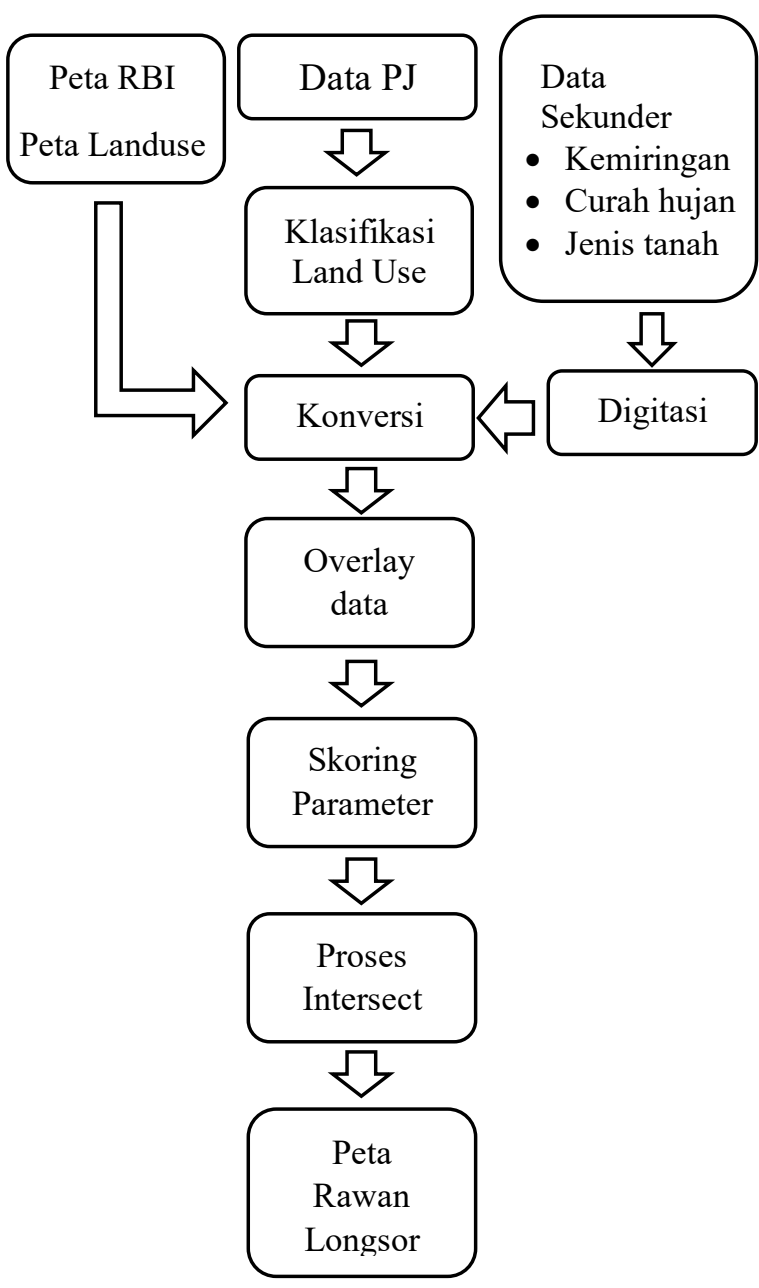

Pemetaan Ancaman Bencana tanah Longsor

Dalam proses pemetaan peta potensi kerawanan bencana longsor ini melewati berbagai macam proses seperti pembuatan peta penggunaan lahan,peta kemiringan lereng,peta 
jenis tanah,peta geologi dan peta curah hujan dimana semuanya merupakan parameter longsor.

\section{Peta curah hujan}

Pada pembuatan peta curah hujan ini dimanfaatkan data curah hujan dari stasiun cuaca yang ada di sekitar cimahi dimana dimanfaatkan metode isohyet dimana metode ini adalah menghubungkan garis garis dengan curah hujan yang sama.Pembuatan peta curah hujan menggunakan toolbox idw interpolation dimana jika sudah dilakukan maka dilakukan pengharkatan atau pembobotan yang merujuk jurnal tehnik ITS (Putri, 2016)

\begin{tabular}{|l|l|l|}
\hline \multirow{4}{*}{ Curah Hujan } & Besaran & Skor \\
\cline { 2 - 3 } & $<1000$ & 1 \\
\cline { 2 - 3 } & $1000-2000$ & 2 \\
\cline { 2 - 3 } & $2000-2500$ & 3 \\
\cline { 2 - 3 } & $2500-3000$ & 4 \\
\cline { 2 - 3 } & $>3000$ & 5 \\
\hline
\end{tabular}

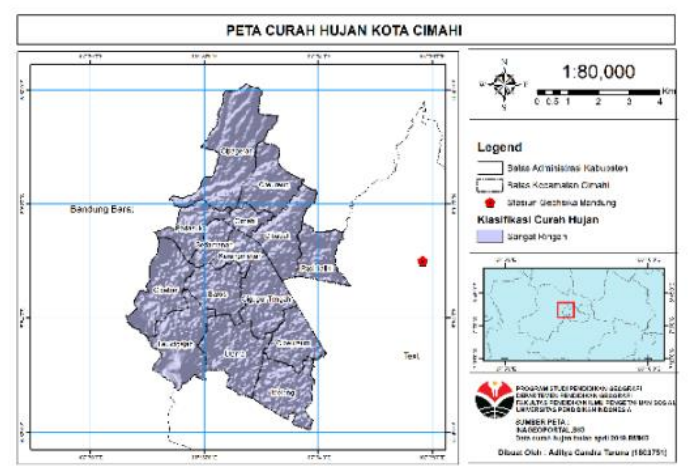

\section{Peta Kemiringan Lereng}

Pembuatan peta kemiringan lereng ini memanfaatkan citra DEM SRTM kota cimahi dimana pada pelaksanaanya menggunakan tools clip sehingga data DEM SRTM sesuai dengan wilayah kajian yakni wilayah kajian kota Cimahi selanjutnya jika SHP sudah berhasil di Clip lalu dilakukan proses Slope sehingga menunjukan kemiringan lereng dari data DEM SRTM yang sudah di clip yang pada akhirnya akan dilakukan Reclassify untuk menemukan kelas-kelas kemiringan lereng lalu selanjutnya dilakukan proses pembobotan yang merujuk pada jurnal tehnik ITS (Putri, 2016).

\begin{tabular}{|c|c|c|}
\hline \multirow{4}{*}{$\begin{array}{c}\text { Kemiringan } \\
\text { Lereng }\end{array}$} & Besaran & Skor \\
\cline { 2 - 3 } & $0-8 \%$ & 1 \\
\cline { 2 - 3 } & $8-15 \%$ & 2 \\
\cline { 2 - 3 } & $15-25 \%$ & 3 \\
\cline { 2 - 3 } & $25-45 \%$ & 4 \\
\cline { 2 - 3 } & $>45$ & 5 \\
\hline
\end{tabular}

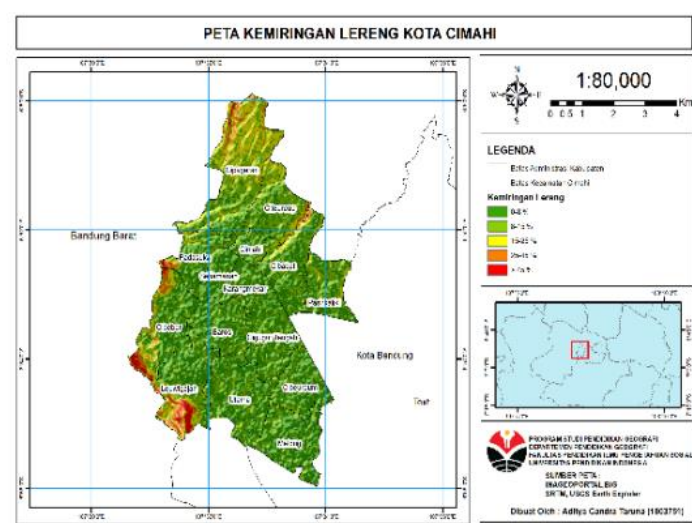

\section{Peta penggunaan Lahan}

Pada pembuatan peta penggunaan lahan di kota Cimahi data didapatkan dari INAGeoportal yang sudah tersedia yang selanjutnya akan disesuaikan dengan penggunaan lahan yang ada di Kota cimahi dengan cara dilakukan pemanggilan data Pada Arcgis selanjutnya jika seluruh wilayah kajian sudah terisi dilakukan pembobotan disesuaikan dengan jurnal tehnik ITS (Putri, 2016)

\begin{tabular}{|c|l|c|}
\hline \multirow{5}{*}{$\begin{array}{c}\text { Penggunaan } \\
\text { Lahan }\end{array}$} & $\begin{array}{l}|c| \\
\text { Butan,vegetasi lebat } \\
\text { dan badan air }\end{array}$ & 1 \\
\cline { 2 - 3 } & $\begin{array}{l}\text { Kebun dan campuran } \\
\text { semak belukar }\end{array}$ & 2 \\
\cline { 2 - 3 } & $\begin{array}{l}\text { Perkebunan dan sawah } \\
\text { irigasi }\end{array}$ & 3 \\
\cline { 2 - 3 } & $\begin{array}{l}\text { Kawasan industri dan } \\
\text { pemukiman }\end{array}$ & 4 \\
\cline { 2 - 3 } & Lahan kosong & 5 \\
\hline
\end{tabular}

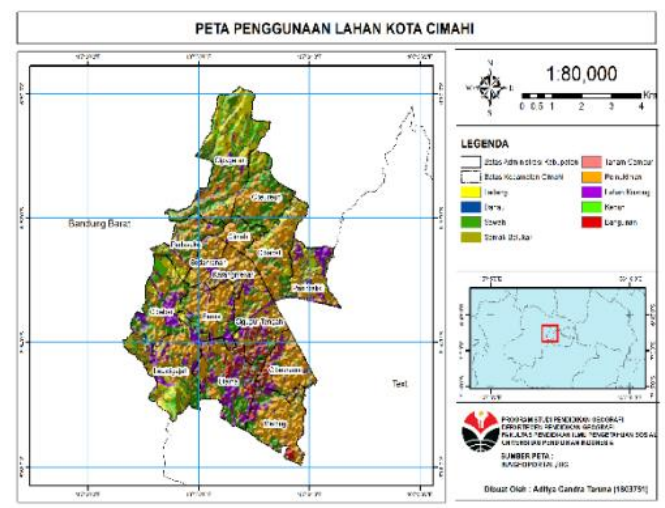




\section{Peta Geologi}

Pembuatan peta geologi kota Cimahi dilakukan dari data yang didapatkan dari BIG sehingga pembuatan peta hanya dengan cara melakukan pemanggilan data pada Arcgis sehingga peta persebaran geologi Kota Cimahi sudah didapatkan selajutnya dilakukan pembobotan merujuk jurnal tehnik (Putri, 2016)

\begin{tabular}{|c|l|c|}
\hline \multirow{5}{*}{ Geologi } & Besaran & Skor \\
\cline { 2 - 3 } & Bahan Alluvial & 1 \\
\cline { 2 - 3 } & Bahan Vulkanik & 2 \\
\cline { 2 - 3 } & Bahan Sedimen & 3 \\
\cline { 2 - 3 } & $\begin{array}{l}\text { Bahan sedimen } 2 \\
\text { vulkanik 2 }\end{array}$ & 4 \\
\hline
\end{tabular}

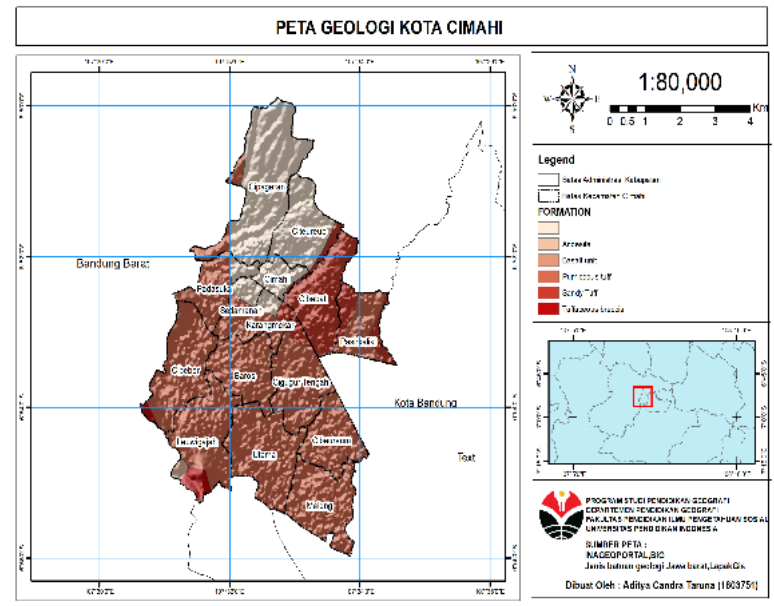

\section{Peta Jenis tanah}

Pembuatan peta jenis tanah kota Cimahi dilakukan dengan cara mengambil data yang sudah tersedia di BIG sehingga pembuatanya hanya dengan melakukan pemanggilan data pada aplikasi Arcgis sehingga ketika peta jenis tanah kota cimahi sudah berhasil dibuat maka dilakukan proses pembobotan disesuaikan dengan penelitian yang dilakukan oleh (Darmawan et al., 2017)

\begin{tabular}{|c|l|l|c|}
\hline \multirow{4}{*}{ Jenis } & Besaran & Infiltrasi & Skor \\
\cline { 2 - 4 } Tanah & Andosol & Peka & 2 \\
\cline { 2 - 4 } & Gleisol & Agak peka & 4 \\
\cline { 2 - 4 } & Podsolik & Peka & 2 \\
\hline
\end{tabular}

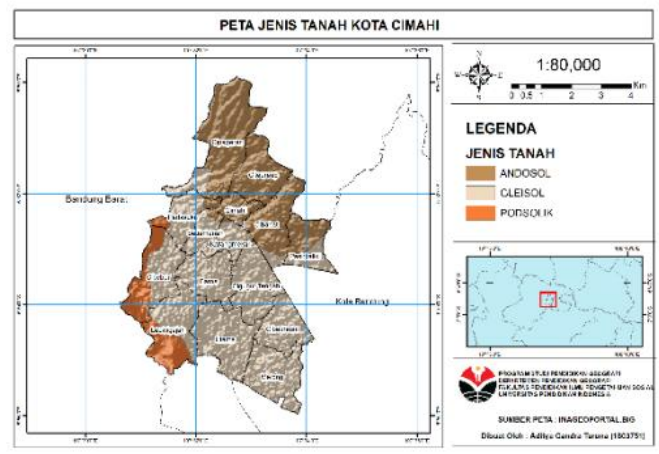

\section{HASIL DAN PEMBAHASAN \\ Penentuan daerah rawan Longsor}

Setelah setiap parameter yang diperlukan dalam hal membuat peta daerah rawan longsor seperti peta curah hujan,peta kemiringan lereng,peta geologi,peta jenis tanah dan peta penggunaan lahan sudah selesai dilakukan dan sudah dilakukan proses pengskoran tiap parameter maka dilakukan pengkalian antar harkat yang ada sehingga dihasilkan data kombinasi dari berbagai parameter yang ada sehingga diharapkan daerah dengan potensi longsor paling tinggi dapat dimunculkan.Pengkalian harkat dapat digunakan rumus :

\section{HCH x HKL x HJT x HJG x HPL}

Ket :

$\mathrm{HCH}=$ Harkat Curah Hujan

HKL = Harkat Kemiringan Lereng

HJT = Harkat Jenis Tanah

HJG = Harkat Jenis Geologi

HPL = Harkat Penggunaan Lahan

Pengkalian harkat harkat dari berbagai parameter longsor ini menjadi sebuah data utama dalam menghasilkan peta daerah rawan longsor kota cimahi dimana penentuan tingkat kerawanan daerah bencana rawan longsor diatas menunjukan hasil perkalian antara 12192 yang selanjutnya akan dikonversikan ke beberapa tingkatan sesuai dengan kebutuhan dimana saya membagi tingkat kerawanan menjadi 5 kelas yakni sangat rendah,rendah,sedang,tinggi dan sangat tinggi dimana pada penentuan interval tingkat kerawanan akan dilakukan perhitungan sebagai berikut : 
Nilai Max $=192$

Nilai Min $\quad=12$

Nilai Interval $=\frac{192-12}{5}=36$

Maka dari hasil analisis diatas diketaui bahwa setiap kelas memiliki perbedaan sebesar 36 dimana terdapat 5 klasifikasi dengan interval dimana ini akan membatasi tiap kelas pada masing masing klasifikasi yang ada sehingga maka diketahui tingkat kerawanan sebagai berikut :

\begin{tabular}{|c|l|c|}
\hline No & \multicolumn{1}{|c|}{ Klasifikasi } & Skor \\
\hline 1. & Sangat rendah & $12-48$ \\
\hline 2. & Rendah & $48-84$ \\
\hline 3. & Sedang & $84-120$ \\
\hline 4. & Tinggi & $120-156$ \\
\hline 5. & Sangat Tinggi & $156-192$ \\
\hline
\end{tabular}

Berdasarkan analisis mengenai luasan daerah rawan longsor di kota cimahi maka luasan masing masing klasifikasi sebagai berikut :

\begin{tabular}{|c|l|c|}
\hline No & Klasifikasi & $\begin{array}{c}\text { Luasan } \\
\text { (Ha) }\end{array}$ \\
\hline 1 & Sangat rendah & 2636 \\
\hline 2 & Rendah & 675 \\
\hline 3 & Sedang & 578 \\
\hline 4 & Tinggi & 4 \\
\hline 5 & Sangat tinggi & 262 \\
\hline
\end{tabular}

Berikut merupakan hasil peta dimana datanya merupakan hasil dari perkalian pengharkatan berbagai parameter yang ada

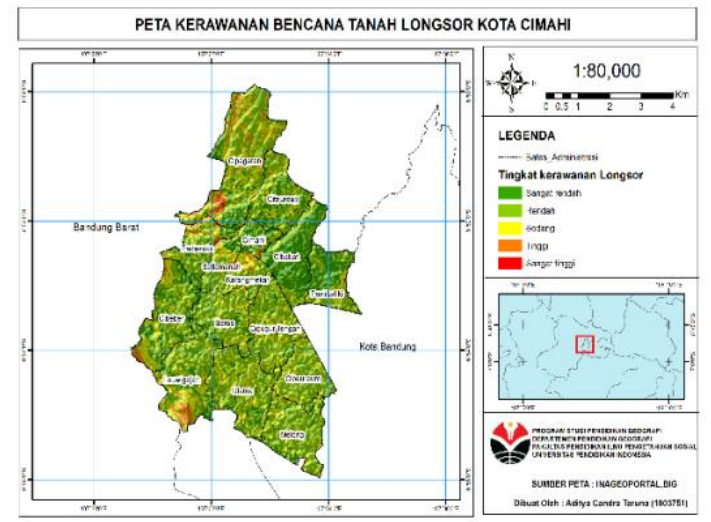

\section{KESIMPULAN}

Tingkat kerawanan bencana longsor di kota Cimahi dapat dilihat dari peta hasil overlay beberapa parameter yang ada di kota cimahi yakni curah hujan,kemiringan lereng,jenis batuan geologi,jenis tanah dan penggunaan lahan di kota Cimahi.Dari Hasil peta Kerawanan bencana longsor di kota cimahi dapat disimpulkan bahwa daerah yang memiliki tingkat kerawanan longsor sangat tinggi berada di kecamatan cimahi tengah bagian barat dimana berbatasan langsung dengan kelurahan cipageran, sedangkan daerah yang menunjukan kerawanan longsor tingkat tinggi berada di kecamatan cimahi selatan tepatnya terkonsentrasi di kelurahan leuwigajah dan sedikit di selatan cibeber ,bagian utara kelurahan setiamanah dan karangmekar.Sedangkan untuk kerawanan tingkat sedang ada di bagian tengah kelurahan leuwigajah bagian tengah cipageran,melong, utama, cibereum dan Pasir kaliki.Untuk kerawanan tingkat rendah dapat ditemui di kelurahan citereup,utama ,baros,cigugur tengah dan Melong.Dan yang terakhir untuk kerawanan longsor tingkat sangat rendah Ada pada sekitar kelurahan cibabat dan disekitar pusat kota Cimahi

\section{REKOMENDASI}

Untuk mendukung pemetaan potensi bencana longsor di kota cimahi alangkah lebih baiknya agar dilakukan sebuah pengamatan secara langsung (Groundcheck) dimana fungsinya adalah untuk melihat kondisi real time di lapangan serta memastikan ada penggunaan lahan apasaja yang ada di kawasan yang memiliki tingkat potensi kerawanan bencana longsor yang tinggi sehingga output dari penelitian ini dapat berfungsi sebagai warning system terhadap masyarakat untuk aware terhadap potensi longsor di sekitarnya dan acuan tambahan untuk melakukan pemetaan multi risk assignment dimana pemetaan jenis ini akan lebih mendetail mengenai tingkat kapasitas masyarakat dan kerentanan terhadap potensi longsor yang mungkin terjadi di kota cimahi. 


\section{DAFTAR PUSTAKA}

Suwaryo, P. A. W., \& Yuwono, P. (2017).

Faktor-faktor yang mempengaruhi tingkat pengetahuan masyarakat dalam mitigasi bencana alam tanah longsor. Urecol 6th, 305-314.

Samsul Arifin, Ita Carolina, W. C. (2006). Implementasi Penginderaan Jauh dan SIG untuk Inventarisasi Daerah Rawan Bencana Longsor. Jurnal

Penginderaan Jauh Dan Pengolahan Data Citra Digital, 3, 77-86.

http://www.jurnal.lapan.go.id/index.php/j urnal_inderaja

Putri, A. R. (2016). Identifikasi Daerah Rawan Tanah Longsor Menggunakan SIG (Sistem Informasi Geografis) (Studi Kasus : Kabupaten Kediri). Jurnal Teknik ITS, 5(2).

https://doi.org/10.12962/j23373539.v5i2. 17237

Darmawan, K., Hani'ah, H., \& Suprayogi, A. (2017). Analisis Tingkat Kerawanan Banjir Di Kabupaten Sampang Menggunakan Metode Overlay Dengan Scoring Berbasis Sistem Informasi Geografis. Jurnal Geodesi Undip, 6(1), 31-40.

Safitri, S. (2015). El Nino , La Nina dan Dampaknya Terhadap Kehidupan. Jurnal Criksetra, 4(8), 153.

Apriyono, A. (2009). Analisis Penyebab

Tanah Longsor di Kalitlaga

Banjarnegara. 5(1). 